\title{
ISOLASI DAN KARAKTERISASI Pseudomonas sp DARI LIMBAH FENOL SERTA KEMAMPUAN BIODEGRADASINYA
}

\author{
Sriani Hendarko*, MG Isworo Rukmi*, Agustina Indrawati** \\ * Jurusan Biologi FMIPA UNDIP Semarang** BAPEDA Pemda Semarang
}

\begin{abstract}
ABSTRAK
Fenol diketahui sebagai senyawa hidrokarbon yang bersifat toksis, yang dalam konsentrasi tinggi dapat berbahaya bagi kehidupan mahluk hidup termasuk manusia. Pada konsentrasi yang tinggi, senyawa fenol dalam suatu lingkungan dapat didegradasi oleh mikroorganisme teruta-ma oleh bakteri kelompok hidrokarbonolastik yang dapat menggunakan hidrokarbon sebagai sumber $\mathrm{C}$ untuk kehidupannya. Bakteri Pseudomonas adalah salah satu dari kelompok ini. Tujuan dari penelitian ini untuk men-dapatkan isolat Pseudomonas dari sumber alam yang mampu mendegradasi senyawa fenol dan untuk menguji hubungan antara degradasi fenol dengan pertumbuhan bakteri Pscudomonas. Bakteri Pseudomonas yang digunakan dalam penelitian ini diisolasi dari limbah industri farmasi "P" di Semarang pada bulan Desember 1995. Tiga konsentrasi fenol yang berbeda diberikan dalam media yaitu $0,1 \mathrm{mg} / \mathrm{l}$ (F1), 0,2 mg/l (F2), $0,3 \mathrm{mg} / \mathrm{l}$ (F3) dan $0,0 \mathrm{mg} / 1$ sebagai kontrol. Pertumbuhan bakteri diuji dengan mengukur kerapatan optis pada panjang gelombang $(\lambda) 640 \mathrm{~nm}$, sedang perubahan kandungan fenol dalam media diuji menggunakan "Direct Photometric method" memurut Greenberg ${ }^{(6)}$. Hasil dari penelitian ini menunjukkan bahwa Pseudomonas $s p$ yang diisolasi dari limbah industri mempunyai kemampuan untuk mendegradasi senyawa fenol. Bakteri diisolasi dan diidentifikasi menggunakan Cowan dan Steel ${ }^{(12)}$. Kerapatan optis tertinggi sebagai parameter pertumbuhan dijumpai pada F3 $(0,2170)$, F2 $(0,2076), \mathrm{F} 1(0,1938)$ dan $\mathrm{F} 0(0,0315)$, sedang rata-rata waktu inkubasi adalah $16 \mathrm{jam}(\mathrm{F} 1, \mathrm{~F} 2, \mathrm{~F} 3)$ dan 10 jam untuk $\mathrm{F} 0$. Kurva pertumbuhan pada F1, F2 dan F3 mulai menurun setelah 20 jam dan 14 jam untuk F0. Makin lama waktu inkubasi degradasi senyawa fenol dalam media makin tinggi.
\end{abstract}

Kata Kunci : Fenol, Mikroorganisme, Degradasi

\section{ABSTRACT}

\section{Isolation and Characterisation of Pseudomonas sp from Phenol Waste and Its Biodegradation Capability}

Phenol has been known as a toxic hydrocarbon compound which in high concentration can be dangerous for living organism including human being. The high concentration of phenol com-pound in the environment can be degraded by microorganism activities especially the bacteria of the hydrocarbonoclastic group which can be used hydrocarbon as $C$ source for their living activitics. The bacteria Psudomonas is the one of the group. The aims of the study were to find Pseudomonas isolate from natural source that have activities in degrading phenol com-pound \& to examine the relationship of phenol degradation with the population growth of the bacteria. The bacteria Psetidomonas $s p$ used in this study was isolated from waste water of the pharmaceutical factory " $\mathrm{P}$ " in Semarang December 1995. Three different phenol concen-tration in the media were used in this study i.e. $0.1 \mathrm{mg} / \mathrm{F} 1), 0.2 \mathrm{mg} /(\mathrm{F} 2), 0.3$ $\mathrm{mg} / \mathrm{l}(\mathrm{F} 3)$ and $0.0 \mathrm{mg} / \mathrm{l}$ (F0) used as control. The growth of the bacteria was examined by measuring the op-tical density at $\lambda 640 \mathrm{~nm}$, while the changes of the phenol content in the media was examined using "direct photometric method" according to Greenberg et.al. The result of the study showed that the Psetudomonas $s p$ isolated from waste water of the pharmaceutical factory has the ability on degrading phenol compound. The bacteria isolate was identified using Cowan and Stecl method. The highest optical density as a growth parameter were found in the F3 (0.2170), F2 (0.2076), F1 (0.1938) and F0 (0.0315) respectively, while the average of incu-bation time were 16 hours (F3, F2, F1) and 10 hours for F0. The growth curve in F1, F2, F3 started to decrease in 20 hours of incubation and 14 hours for F0. The longer the incubation time the higher degradation of phenol compound in the media.

Key word: Phenol, Microorganism, Degradation. 


\section{PENDAHULUAN}

Pencemaran fenol dalam suatu perairan dapat berasal dari limbah industri yang menggunakan senyawa fenol dalam prosesnya atau menggunakan fenol sebagai bahan baku.

Fenol adalah suatu senyawa organik yang bersifat toksik dan mudah larut dalam air, sehingga mudah mencemari suatu perairan yang mengakibatkan kualitasnya me-nurun serta menyebabkan gangguan terhadap ekosistem lingkungan perairan tersebut ${ }^{(2)}$.

Konsentrasi fenol dalam perairan di atas $0,1 \mathrm{mg} / \mathrm{l}$ dapat mengganggu kesehatan ternak, burung-burung dan manusia ${ }^{(3)}$. Standar kualitas air yang baik untuk air minum menurut peraturan yang dikeluarkan Menteri KLH 1988 konsentrasi fenol maksimal $0,002 \mathrm{mg} / \mathrm{l}$. Sedang untuk keperluan perikanan dan peternakan konsentrasi fenol maksimal $0,001 \mathrm{mg} / 1^{(4)}$. Dari penelitian pendahuluan diketahui bahwa limbah dari pabrik "P" di Semarang mengandung senyawa fenol sebesar $0,2 \mathrm{mg} / \mathrm{l}$.

Untuk mengatasi pencemaran fenol dalam suatu perairan dapat dilakukan dengan menurunkan konsentrasinya sesuai dengan standart kualitas air.

Penurunan konsentrasi dapat dilakukan dengan menggunakan mikroorganisme yang mempunyai sifat hidrokarbonoklastik yaitu mikroorganisme yang dapat menggunakan senyawa hidrokarbon sebagai satu-satunya sumber karbon ${ }^{(5)}$. Salah satu genus bakteri yang diketahui mempunyai potensi menurunkan senya- wa fenol adalah genus Pseudomonas sp, dan bakteri ini diharapkan dapat diisolasi dari perairan yang akan diteliti ${ }^{(5)}$.

\section{METODE PENELITIAN}

Penelitian pencemaran fenol dalam suatu perairan dilakukan di Laboratorium Mikrobiogenetika Jurusan Biologi FMIPA Undip Semarang pada bulan Desember 1995-Juni 1996.

Sampel air diambil secara aseptis dari kolam pembuangan limbah pabrik farmasi "P" di Semarang.

Isolasi mikroorganisme dilakukan dengan metode taburan dan goresan menggunakan medium selektif Centrimide Agar dan medium Nutrien Agar. Identifikasi isolat bakteri dilakukan berdasarkan uji karakterisasi secara biokimia sesuai dengan metode Cowan $\&$ Steel ${ }^{(12)}$.

Pertumbuhan mikroorganisme diamati dengan mengukur kerapatan optis (OD) pada panjang gelombang $640 \mathrm{~nm}$ dan pengukuran konsentrasi fenol dalam medium dilakukan dengan metode "Direct Photometric" menurut Greenberg ${ }^{(6)}$.

\section{HASIL DAN PEMBAHASAN}

Dari penelitian perairan limbah pabrik far masi "P" di Semarang yang tercemar se-nyawa fenol dengan konsentrasi $0,2 \mathrm{mg} / 1$ ditemukan isolat Pseudomonas $s p$ yang mampu menurunkan senyawa fenol dalam perairan karena dapat menggunakan senyawa hidrokarbon sebagai satu-satunya sumber karbon. 
Tabel 01. Hasil Uji Karakterisasi Isolat Bakteri

\begin{tabular}{|l|c|c|}
\hline \multicolumn{1}{|c|}{ Uji Karakterisasi } & Hasil & Literatur \\
\hline Pewamaan Gram & + & + \\
Bentuk morfologi & rod & rod \\
Motilitas & + & + \\
Produksi katalase & + & + \\
Hugh and Leifson's & oksidatif & oksidatif \\
Pertumbuhan anaerob & + & + \\
Prod asam glukosa & + & + \\
Oksidase & tidak & + \\
\hline
\end{tabular}

* Sumber : Cowan (1975)

Dengan uji pertumbuhan isolat Pseudomonas sp pada medium fenol sebagai satu-satunya sumber karbon yang menunjukkan adanya pertumbuhan dibandingkan dengan medium yang tidak mengandung fenol.

Hasil diatas menunjukkan bahwa isolat Pseudomonas sp mampu menggunakan senyawa fenol sebagai sumber karbon untuk menghasilkan enersi dan material seluler untuk pertumbuhannya ${ }^{(6)}$.

Analisis pertumbuhan dan degradasi senyawa fenol oleh isolat bakteri dalam penelitian ini dilakukan dengan menggunakan 3 macam konsentrasi fenol yang berbeda yaitu $0,1 \mathrm{mg} / \mathrm{l}$ (F1) ; 0,2 $\mathrm{mg} / \mathrm{l}$ (F2) ; 0,3 mg/l (F3) serta $0 \mathrm{mg} / \mathrm{l}$ (F0) sebagai kontrol. Hasil pengamatan menunjukkan adanya perbedaan pertumbuhan untuk masing-masing konsentrasi, ini dapat dilihat pada kurva pertumbuhan (Gb. 3) ; yaitu adanya peningkatan nilai kerapatan optis yang berbeda nyata di- bandingkan dengan kontrol untuk masing-masing konsentrasi ; F3(0,2170), F2 $(0,2076), F 1(0,1938)$ dan $F 0(0,0315)$. Antara perlakuan F2 dan F3 perbedaan peningkatan kerapatan optis tidak terlalu besar ini kemungkinan karena perbedaan konsentrasi fenol yang diberikan dalam medium kurang besar.

Dari hasil pengamatan dapat pula dilihat bahwa masa inkubasi juga berpengaruh terhadap pertumbuhan isolat (Gb. 03).

Nilai kerapatan optis tertinggi untuk kontrol (F0) dicapai pada masa inkubasi 10 jam (T6) dan 12 jam (T1) ; sedang untuk perlakuan F1, F2 dan F3 nilai kerapatan optis tertinggi dicapai pada masa inkubasi 16 jam (T9), sehingga bentuk kurva pertumbuhan relatif lebih tinggi dan panjang (Gb.03). Adanya perbedaan pertumbuhan dalam medium fenol menunjukkan bahwa Pseudomonas sp dapat mendegradasi senyawa fenol dari senyawa kompleks menjadi senyawa yang lebih sederhana dan dihasilkan energi dan material seluler yang dapat menunjang pertumbuhannya.

Mekanisme degradasi senyawa fenol dari senyawa kompleks menjadi senyawa yang lebih sederhana disebabkan adanya enzim fenol hidrolase yang akan merubah senyawa fenol dari bentuk cincin aromatis menjadi senyawa alifatis yang langsung dapat memasuki rantai metabolisme untuk menghasilkan enersi

Enzim fenol hidrolase merubah fenol menjadi katekol. Katekol 2,33 dioksigenasi menjadi senyawa alifatis yang selanjutnya akan dihasilkan asam piruvat dan asetil Co A dengan adanya enzim 4 hi- 
droksi 2 oksovalerat aldolase dan aldehid dehydrogenase (Gb. 01) ${ }^{(14)}$.

Terlihat pada $\mathrm{Gb}$. 04 bahwa dengan bertambahnya masa inkubasi nilai kerapatan optis kultur Pseudomonas sp makin meningkat, sedang konsentrasi fenol makin menurun.

\section{KESIMPULAN}

Dari hasil penelitian dapat disimpulkan :

1. Dari air limbah pabrik obat "P" yang tercemar fenol dapat diisolasi isolat Pseudomonas sp.

2. Pertumbuhan Pseudomonas sp dipengaruhi oleh konsentrasi fenol dalam medium dan masa inkubasi.

3. Makin tinggi konsentrasi fenol dalam medium pertumbuhan Pseudomonas sp makin baik, demikian pula dengan jumlah fenol yang terdegradasi makin besar.

4. Masa inkubasi berpengaruh langsung terhadap pertumbuhan maupun degradasi fenol.

\section{UCAPAN TERIMA KASIH}

Ucapan terima kasih disampaikan kepada Dr. Bambang Cahyono, atas masukan dan koreksi makalah ini.

\section{DAFTAR PUSTAKA}

1. Greenberg, E, S.L. Aksceri dan D. Eaton., 1992., Standard Methods for the Examination of Water and Waste Water. American Public Health Association, Washington.

2. Udiharto, M. dan Nugroho Hadi. 1997., Degradasi Fenol dalam Air Limbah Kilang Minyak Cepu dengan menggu- nakan Kultur Campuran, Lembaran Publikasi Lemigas, No 3/1997. Hal 213 217.

3. Mettlev, V.V., A.1. Kanaev dan N.G. Dzasokhovia., 1983., Water Toxicology. American Publishing Co. Pvt. Ltd., New Delhi.

4. Timotius. K.H. 1982. Keputusan Menteri KLH No Kep 02/Men/KLH/I/1988 tentang Pedoman Penerapan Baku Mutu dalam Mikrohiologi Dasar, Universitas Kristen Satya Wacana Salatiga.

5. Kadarwati, S., 1989, Pengaruh Kandungan Air Pada Pertumbuhan Resorfotomaculum dalam Avtur Padat. Penelitian dan Pengembangan Teknologi Minyak dan Gas Bumi. Lemigas., Jakarta.

6. Pelczar, M.J. dan E.C.S. Chan. 1981. Elemen of Microbiology. Mc Graw-Hill, Inc, New York.

7. Brock, D. Thomas., W.d. Smith dan M.T. Madigan, 1991, Biology of Microorganism, Fourth Edition., PreuticeHall., New York.

8. Austin, B., 1988. Marime Microbiology, Cambridge University Press, Cambridge

9. Jobson, A., F.D. Cook dan W.S. Westlake, 1972., Microbial Utilization of Crude Oil, Appl, Env. (Microb. 23 : 1082-1089).

10. Walker, J.D. dan R.R. Colwell.1976. Enumeration of Petroleum degrading Microorganism., Appl. Env Microb. 31 : $198-207$.

11. Cowan, S.T., 1975, Cowam and steel's Mamual of The Identification of Medical 
Bacteria. Second edition Cambridge.

University Press, London.

12. Gaudy A dan E. Gaudy, 1981. Microbiology Environmental Scientish And Engineer., Mc Graw-Hill International Book Co. Auckland.

13. William, A dan R. Sayers, 1994., Biodegradation, Vol 5., Kluwer Academic Publishers. Netherlan. 